PRZEGLĄD BIBLIOTECZNY 2020 z. 3 PL ISSN 0033-202X

\author{
MAREK NAHOTKO \\ Instytut Studiów Informacyjnych \\ Uniwersytet Jagielloński \\ e-mail: marek.nahotko@uj.edu.pl \\ ORCID: 0000-0002-4823-8080
}

\title{
SAMOPOZNANIE W KOMUNIKACJI NAUKOWEJ
}

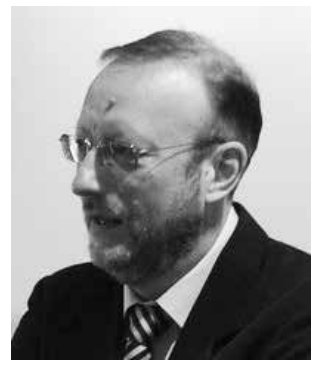

Dr hab. Marek Nahotko, prof. UJ, zatrudniony w Instytucie Studiów Informacyjnych Uniwersytetu Jagiellońskiego, specjalizuje się $\mathrm{w}$ problemach organizacji informacji, $\mathrm{w}$ tym metadanych dokumentów elektronicznych oraz wykorzystania Internetu i dokumentów elektronicznych w komunikacji naukowej i działalności informacyjnej. Jest autorem książek Teoria gatunków w organizacji informacji i wiedzy (Kraków, 2018), Komunikacja naukowa w środowisku cyfrowym (Warszawa, 2010), Naukowe czasopisma elektroniczne (Warszawa, 2007), Opis dokumentów elektronicznych. Teoretyczny model i możliwości jego aplikacji (Kraków 2006), Metadane: sposób na uporządkowanie Internetu (Kraków, 2004) oraz licznych artykułów publikowanych m.in. na łamach "Information Research", "Cataloging \& Classification Quarterly", "Przeglądu Bibliotecznego", „Zagadnień Informacji Naukowej” oraz „Bibliotheca Nostra”.

SŁOWA KLUCZOWE: Samopoznanie. System biblioteczny. Analizy informacji indywidualnej. Komunikacja naukowa.

ABSTRAKT: Teza/cel artykułu - W artykule przedstawione zostały zagadnienia samopoznania i analiz informacji indywidualnej $w$ dwóch zastosowaniach $w$ obszarze komunikacji naukowej - publikowaniu naukowym i organizacji informacji w bibliotekach. Metody badań - Krytyczna analiza piśmiennictwa przedmiotu wykorzystana została do omówienia zjawiska samopoznania (ang. Quantified Self, QS) oraz jego występowania w zastosowaniu nieopisywanym dotąd w literaturze przedmiotu. Dokonano analizy funkcjonalnej przykładowego syste- 
mu społecznościowego dedykowanego nauce (ResearchGate) oraz narzędzi QS udostępnianych wraz z artykułami naukowymi wydawnictwa PLOS. Podobną analizę wykonano dla zintegrowanych systemów bibliotecznych, ze szczególnym uwzględnieniem OPAC 2.0. Wyniki - Miary ilościowe aktywności ludzkiej stosowane były od zawsze, jednak nowe technologie komputerowe również w tym zakresie stały się przyczyną istotnych zmian. Metody i narzędzia QS, stosowane początkowo głównie w obszarze ochrony zdrowia i kultury fizycznej, znalazły szerokie zastosowanie w wielu innych obszarach, w tym także w komunikacji naukowej. Dokonane analizy wykazały szerokie stosowanie nowych miar ilościowych w badanych obszarach komunikacji naukowej. Stosowanie tych miar z jednej strony, pozwala na dokumentowanie przejawów wielu aktywności ludzkich, w tym komunikacji naukowej, a z drugiej strony, służy dokonywaniu zmian w zachowaniach (również informacyjnych) użytkowników nowych technologii, służących doskonaleniu tych aktywności. Wnioski - Samopoznanie i analizy informacji indywidualnej (ang. self-tracking) są kolejnymi kierunkami dostosowywania systemów informacyjnych (w tym systemów bibliotecznych), stosowanych w komunikacji naukowej, do kierunków rozwoju systemów komputerowych ogólnego stosowania. W publikowaniu naukowym przejawem tych zmian jest powszechne stosowanie miar alternatywnych. W systemach bibliotecznych ich przejawem są nowe funkcjonalności kolejnych generacji tych systemów, ułatwiających komunikację użytkowników z systemem i między sobą.

\section{WSTĘP}

We współczesnym społeczeństwie w coraz większym zakresie stosowane są urządzenia służące do gromadzenia i analizowania informacji o otaczającym świecie, w tym także o ich użytkowniku jako części tego świata. Informacje takie, dotyczące np. pogody, parametrów organizmu lub wydajności zawodowej, zawsze były tworzone i analizowane za pomocą narzędzi analogowych (np. wag, termometrów). Podobnie jak $\mathrm{w}$ wielu innych miejscach, gdzie organizowana jest informacja, również tu zastosowano nowe technologie cyfrowe, które stworzyły także w tym zakresie nowe, znacznie większe i bardziej dostępne możliwości gromadzenia, przetwarzania i udostępniania informacji. Technologie takie wtapiają się w czynności życia codziennego, co wywołuje wiele pytań i wątpliwości co do dopuszczalnego zakresu i sposobu technologicznej mediacji, uczestniczącej w modyfikacji i kształtowaniu ludzkiego życia. Wielu autorów, (np. Hayles, 2006; Latour, 2005; Lupton, 2016a), uważa, że obecny rozwój społeczeństw cechuje się coraz bardziej intensywnymi interakcjami ludzi z wytworami technologii, co powoduje, że problemy te stanowią interesujący obszar badawczy.

Urządzenia elektroniczne w coraz większym stopniu wspomagają naturalną zdolność ludzi do monitorowania i analizy informacji pochodzącej ze środowiska. Urządzeń tych, a więc również produkowanej przez 
nie informacji, jest coraz więcej. Można mówić wręcz o eksplozji praktyk monitorowania skierowanego na samego siebie (Neff \& Nafus, 2016, p. 1). Biegacze rzadko obywają się bez urządzeń noszonych na ciele, wskazujących podstawowe parametry organizmu, takie jak tętno, ciśnienie krwi, temperaturę, częstość oddechu, pułap tlenowy oraz parametry środowiska (temperatura i wilgotność powietrza, ciśnienie atmosferyczne i in.). Pracownicy biurowi, $w$ tym bibliotekarze, podczas przerw w czynnościach służbowych kontrolują ${ }^{1}$ ilość czasu, który spędzają grając lub zdobywając nowych przyjaciół w serwisach społecznościowych oraz to, z jakim efektem ten czas został spędzony (ilu nowych śledzących dziś zdobyłem?). W gospodarstwach domowych kontrolujemy poziom zużycia energii i porównujemy jej ceny od różnych dostawców. Niebagatelną i mniej rozrywkową rolę spełniają urządzenia wspomagające monitoring niedomagającego organizmu², jak choćby bardzo rozpowszechnione glukometry, które zresztą coraz częściej stosowane są nie tylko przez diabetyków. Wielu stosuje je na przykład po to, aby zoptymalizować efektywność swojego działania poprzez monitorowanie reakcji organizmu na wysiłek.

We wszystkich tych przypadkach informacja poddawana jest działaniom przez indywidualną osobę, może być więc nazywana informacją indywidualną (Materska, 2012, s. 65). Ludzie zarządzają tą informacja, aktywnie współdziałając z urządzeniami technologicznymi, w tym cyfrowymi (choć niekoniecznie), a interakcje te mediują i modyfikują ludzki sposób bycia i percepcji, zachowań i podejmowania decyzji. Urządzenia i informacja wytwarzana $\mathrm{z}$ ich udziałem należą do nowych sposobów postrzegania samego siebie oraz konstruują rozumienie i wyrażanie siebie, powodując, że technologie wpływają nie tylko na tożsamość, ciało i uspołecznienie, ale także na sposób komunikowania i uczenia się (Kristensen \& Ruckenstein, 2018, p. 3625).

Takie tendencje powodują potrzebę stworzenia perspektywy pozwalającej na nowo spojrzeć na indywidualne potrzeby, preferencje i zachowania kształtowane w środowisku komunikacji naukowej, w której zastosowanie znajduje technologia służąca przyswajaniu i zrozumieniu gwałtownie rosnących zasobów informacji. Informacja ta pozostaje nieustrukturyzowanym szumem, dopóki nie zostanie zorganizowana, m.in. w systemach publikowania oraz organizacji, wyszukiwania i udostępniania informacji naukowej. W dalszej części artykułu przedstawione zostanie zagadnienie samopoznania (Quantified Self, QS) oraz monitoringu i analizy parametrów samopoznania (informacji indywidualnej), zwanej self-tracking ${ }^{3}$, jako

${ }^{1}$ Lub sa kontrolowani. Inwigilacja jest ważnym zagadnieniem, poruszanym w literaturze problemu (Liddle et al., 2016).

${ }^{2}$ Szybki rozwój tych urządzeń następuje mimo początkowych błędów w ich działaniu (Wójcik, 2020, s. 43).

${ }^{3} \mathrm{~W}$ dalszej części tekstu terminy te stosowane będą zamiennie w obu językach (polskim 
części zarządzania informacją indywidualna/osobistą (PIM - Personal Information Management). Po krótkim przedstawieniu tych problemów omówione będzie stosowanie tych narzędzi w publikowaniu naukowym jako części komunikacji naukowej. Na koniec podjęta zostanie próba odpowiedzi na pytanie o możliwości i sposoby ich wykorzystania w bibliotekach, również stanowiących część systemu komunikacji naukowej.

\section{SAMOPOZNANIE I ANALIZA INFORMACJI W PIM}

Zachowania informacyjne użytkowników informacji są ważnym i często eksplorowanym obszarem badań informatologii. Wśród nich wiele badań dotyczy zarządzania informacją indywidualna/osobistą w skrócie PIM (Personal Information Management), traktowanego jako obszar badań informatologii. PIM definiowany jest jako praktyka i badania działań realizowanych przez jednostkę w celu pozyskiwania lub tworzenia, gromadzenia, organizowania, zarządzania, wyszukiwania, stosowania i rozpowszechniania informacji dla realizacji zadań (prywatnych lub zawodowych) oraz wypełniania określonych ról społecznych i obowiązków. W PIM szczególną uwagę zwraca się na organizację i zarządzanie kolekcją informacji indywidualnej (Personal Information Collection, PIC) (Jones, 2007, p. 453). Nazywanie tej informacji indywidualną lub osobistą nie oznacza, że nie ma ona znaczenia i oddziaływania społecznego (Krzanowska \& Nahotko, 2018, s. 53). Każda informacja służy komunikowaniu, więc jest częścią procesów społecznych. Informacja funkcjonuje w szerszym, indywidualnym planie zarządzania zapisami (kodyfikowaną informacją), w którym jednostki zarządzają dokumentami w całym swoim życiu. W przypadku informacji indywidualnej chodzi raczej o specyfikę narzędzi i metod stosowanych do zarządzania informacją. W PIM nie są stosowane narzędzia typowe dla zarządzania informacją $\mathrm{w}$ instytucjach, takich jak biblioteki, archiwa i muzea; nie stosuje się dużych systemów informatycznych i metodologii fachowej ${ }^{4}$. Zamiast tego zastosowanie mają wszelkie dostępne narzędzia znajdujące się w najbliższym otoczeniu, od kartki papieru i ołówka, poprzez karteczki samoprzylepne, notatniki i kalendarze po aplikacje w smartfonach i serwisy społecznościowe, które wykorzystywane są z użyciem metod intuicyjnych.

Mark Jones (2012) wskazał trzy rodzaje działań PIM. Są to: wyszukiwanie (prowadzące od potrzeby informacyjnej do informacji, w tym wyszukiwanie informacji nowej i powtórne wyszukiwanie); gromadzenie

\footnotetext{
i angielskim) ze względu na małe rozpowszechnienie w literaturze polskich odpowiedników terminów angielskich, powszechnie stosowanych.

${ }^{4}$ Informacja indywidualna może $z$ takich systemów pochodzić, jednak później jest zarządzana indywidualnie.
} 
(prowadzące od informacji do potrzeby informacyjnej, zastępuje wyszukiwanie, informacja gromadzona jest na wypadek przyszłych potrzeb); oraz działania poziomu meta. Te ostatnie podzielone zostały na cztery kategorie: zarządzanie i organizacja informacji; zarządzanie prywatnością i przepływem informacji; pomiar i ewaluacja informacji; nadawanie sensu i stosowanie informacji. Badania Yuanyuan Feng i Denise Agosto (2019, p. 1361) wykazały, że zastosowanie nowych technologii w PIM powoduje wzrost znaczenia działań poziomu meta kosztem wyszukiwania i gromadzenia. Autorki tłumaczą to przejęciem zadań gromadzenia przez nowe urządzenia, które umożliwiają łatwe dotarcie do wcześniej zgromadzonej informacji. Efektem tego jest przeniesienie wysiłków na działania poziomu meta, takie jak ocena własnych osiągnięć oraz tworzenie celów i planów przyszłych działań.

Takie rozumienie informacji indywidualnej można rozszerzać w różny sposób, na przykład Katarzyna Materska pisze o mojej informacji, którą jednostka może swobodnie rozporządzać i o informacji o mnie, bez względu na to, w czyjej pozostaje dyspozycji (Materska, 2012, s. 66). Cytowana autorka stwierdza jednak, że szczególnie interesująca jest pierwsza z przedstawionych sytuacji, gdy odbiorca, dysponentem i realizatorem działań służących zarządzaniu informacją jest jednostka, gdyż analiza takiego małego świata informacyjnego (Jaeger \& Burnett, 2010) stanowi charakterystykę potrzeb i działań jednostki (w tym oczywiście potrzeb i zachowań informacyjnych) oraz jej miejsca w określonej społeczności.

Nawet w ten sposób ograniczony zakres zainteresowań powinien obejmować wszystkie sfery działań jednostki, zarówno prywatną (rodzinę, znajomych, osoby uprawiające wspólne hobby), jak i zawodową. W zależności od sytuacji informacja indywidualna może być szeroko kolportowana lub wręcz przeciwnie - chroniona przed niepowołanym dostępem. Informacja ta może mieć też różne formy - zarówno tradycyjną jak i elektroniczną choć narzędzia zarządzania tą ostatnią dają szczególnie duże możliwości. Urządzenia te określane są ogólnie technologią analizy aktywności (activity tracking technology, ATT). Sprzęt ATT (np. sensory elektroniczne, smartfony i ich aplikacje, chmura obliczeniowa) staje się coraz bardziej popularny, co przekłada się na powstawanie nowych rodzajów informacji indywidualnej, dotyczącej codziennych aktywności ich użytkowników (Schull, 2016).

Ze względu na treść tego artykułu szczególnie interesujące są badania w zakresie PIM pracowników. Zarządzanie informacją indywidualną pracowników może przynieść przedsiębiorstwu wiele korzyści, w szczegól-

\footnotetext{
${ }^{5}$ Mark Lansdale, twórca terminu PIM (1988, p. 55) pisał o tym zjawisku z psychologicznego punktu widzenia, $z$ zamiarem zrozumienia przyczyn zachowań informacyjnych w pracy biurowej.
} 
ności takim organizacjom, jak uczelnie i inne jednostki badawcze, których głównym produktem jest informacja i wiedza. Odpowiednie wspomaganie PIM pracowników naukowych, np. ułatwienia w dostępie do baz danych, w tym pełnotekstowych, powoduje wzrost wydajności, lepszą pracę zespołowa, efektywniejsze zarządzanie wiedzą (Świgoń, 2012, s. 267). W tym aspekcie nie dziwi polityka udostępniania wielu technologii komunikacyjnych najpierw pracownikom naukowym, skąd rozprzestrzeniały się one zyskując powszechny zasięg. Tak było na przykład z pocztą elektroniczną. Efektywność komunikacyjna sprzyja właściwemu zarządzaniu także innymi dobrami, takimi jak np. czas. Z tego powodu dla celów PIM udostępniane są specjalne systemy, wspomagające zarządzanie informacją przez pracowników naukowych. O systemach tych mowa będzie w dalszej części artykułu.

ATT można określić jako media umożliwiające zróżnicowane, ale powiązane z sobą działania, takie jak gromadzenie zapisów do analiz w systemie elektronicznym, wybór funkcji analiz, które zwykle wbudowane są w interfejs urządzenia, rozpowszechnianie wyników analiz i komunikowanie się $\mathrm{w}$ tym zakresie $\mathrm{z}$ innymi. Wszystkie te działania mają charakter komunikacyjny. Jak pisze James Carey (2009, p. 15), sednem komunikacji jest konstruowanie i zarządzanie uporządkowanym, zrozumiałym, kulturowym światem, który może służyć jako regulator i przestrzeń dla ludzkich działań. Można więc powiedzieć, że ATT służą komunikowaniu informacji związanej z innymi (komunikacyjnymi lub nie) działaniami, na przykład ćwiczeniami fizycznymi ${ }^{6}$. Działania komunikacyjne samopoznania realizują różne, choć współistniejące cele, takie jak dostarczanie informacji o sobie innym (w tym do systemu ATT), formowanie i prezentacja siebie oraz podtrzymywanie w określony sposób zestawu relacji społecznych.

ATT należy do technologii służących analizom informacji indywidualnej, pozwalających uzyskać nową samowiedzę, co jest także celem społeczności samopoznania (ang. QS community). QS jest ruchem społecznym i społecznością w nim uczestniczącą w celu tworzenia analiz ilościowych informacji indywidualnej (self-tracking). Ze względu na ilość przetwarzanych danych bywa zaliczany do zjawiska big data, gdzie informacja indywidualna jest umieszczana w systemach, w których stosuje się kanały przepływu od zasobów tej informacji do hurtowni danych, w których dokonuje się ich analiz (Trace \& Zhang, 2020, p. 292). Analizy te tworzą część większego ekosystemu informacyjnego, pomagającego w budowie indywidualnego rozumienia samego siebie.

${ }^{6}$ Rozróżnienie pomiędzy działaniami komunikacyjnymi i niekomunikacyjnymi jest trudne, gdyż ludzkie działania sa społeczne, a więc wymagające komunikacji. Michał Wendland (2011, s. 209) odróżnił działania komunikacyjne od innych ze względu na dwie cechy: intencjonalność (ze strony nadawcy) i interpretacja (z perspektywy odbiorcy). 
W literaturze funkcjonuje wiele definicji terminu self-tracking (Lomborg \& Frandsen, 2016, p. 1016). Część autorów traktuje to zjawisko z technicznego punktu widzenia, zwracając uwagę na systemy cyfrowe i urządzenia ATT, pozwalające użytkownikom gromadzić, analizować i rozważać znaczenie informacji. Inni określają je jako praktykę gromadzenia, zbierania i uwidoczniania codziennych zachowań, nawyków i reakcji ciała w celu ich zrozumienia i kontroli. Lupton (2014) łączy oba te punkty widzenia technologiczny i proceduralny, definiując self-tracking jako indywidualne zastosowanie technologii do zapisu, monitorowania i refleksji nad cechami życia codziennego. Według cytowanej autorki zastosowanie mediów elektronicznych do self-trackingu może przyjmować wiele form, w zależności od tego, czy jest on dobrowolny (tzn. inicjowany dla siebie samego) i czy jest to działanie prywatne lub społecznościowe.

Z punktu widzenia użytkownika, działania związane $\mathrm{z}$ analizowaniem informacji o swoich aktywnościach są standardową codzienną praktyką związaną ze stosowaniem narzędzi komunikacyjnych w sposób ściśle powiązany z innymi praktykami społecznymi i kulturowymi (praktyki związane z ciałem, obowiązkami służbowymi, rytmem dnia itp.). W związku z tym analizy nie mogą być prowadzone w izolacji, ale muszą uwzględniać ogólniejsze funkcje tych działań w korelowaniu przez użytkownika wymagań, struktur i potrzeb kontekstów codziennego życia. W takiej sytuacji w opisie tych praktyk, oprócz tła dotyczącego problemów technologii informacyjnych, należy uwzględniać przede wszystkim praktyki komunikacyjne jednostek w kontekście codziennych działań.

Praktyki self-trackingu należy traktować jako działania komunikacyjne, gdyż polegają one na przekazywaniu informacji. Można je podzielić na trzy zasadnicze grupy: 1. percepcja (gromadzenie surowych danych); 2. analiza (interpretacja, rozpoznawanie lub modelowanie $z$ użyciem technik przetwarzania danych); 3. informowanie, rozpowszechnianie, perswazja (tworzenie wspólnoty świata informacyjnego przy użyciu narzędzi społecznościowych). Dwa pierwsze zagadnienia są głównie natury technicznej, trzecie dotyczy aspektów społecznych komunikacji w nowym środowisku informacyjnym. W tym zakresie można wyróżnić trzy współzależne kierunki tej komunikacji (Lomborg \& Frandsen, 2016, p. 1019). Po pierwsze, są to interakcje $\mathrm{z}$ informacją akumulowaną w systemie elektronicznym (tzn. narzędziach ATT); po drugie, komunikacja z samym sobą ${ }^{7}$ (reprezentowanym przez informację) i podejmowanie indywidualnych działań; po trzecie, komunikowanie $\mathrm{z}$ innymi, np. ze znajomymi, użytkownikami podobnych systemów, klientami itp.

\footnotetext{
${ }^{7}$ Komunikacja $z$ samym sobą, według cytowanych autorów, ma miejsce, gdy jednostka stosuje ATT do uzyskania danych ilościowych na temat samego siebie, zazwyczaj w celu modyfikacji swojego działania.
} 
Komunikacja z systemem ATT następuje w przypadku wysyłania komunikatu systemu ATT do jego użytkownika na podstawie danych zgromadzonych i przetworzonych przez system. Dla jej realizacji konstruowane są odpowiednie interfejsy, stanowiące bardzo ważną część systemu8. Użytkownik stosuje te interfejsy podczas tworzenia normatywnych zapisów działań $\mathrm{w}$ postaci śladów cyfrowych bitów, które następnie, na podstawie odpowiednich algorytmów są odbierane, analizowane, przechowywane i często ponownie stosowane w przyszłości. Bardzo istotne jest wskazanie na algorytmy, gdyż komunikacja z systemem oznacza $\mathrm{w}$ praktyce komunikację $\mathrm{z}$ twórcą algorytmów i oprogramowania, z projektantem systemu. Sam system zdolny jest jedynie do wyświetlania przygotowanych zawczasu komunikatów i reagowania na informację, do rozpoznawania której został zaprojektowany. Algorytmy nie czynią w ludzkiej komunikacji niczego, do czego ludzie ich nie pobudzają we wrodzonej sobie dążności do łączenia się z innymi. Twórca algorytmów reaguje więc na ślad bitowy, nadaje sens informacji i przygotowuje komunikat dla użytkownika, ewentualnie przekazuje informację dalej. Z drugiej strony, użytkownik również ma wpływ na funkcjonowanie systemu, choć znacznie mniejszy. Jego dane, przetwarzane na podstawie algorytmów, w pewnym (niewielkim) stopniu rekonfigurują system. Może to przybierać formę metadanych, gromadzonych przez system, na podstawie których modyfikowane są jego działania, co uznać można za metakomunikowanie znaczeń budujących tożsamość użytkownika. Dobry algorytm przewiduje możliwość dostosowania systemu do tej tożsamości - na takiej podstawie następuje jego kastomizacja, czasem przyjmująca formę „bańki filtrującej”, która bywa określana jako indywidualny ekosystem informacji, przygotowany przez algorytmy (Książek, 2019, s. 27), czyli w rzeczywistości - ich twórców.

Jak pisze Jack Andersen (2017, p. 8), algorytmy, a dokładniej komunikacja zalgorytmizowana, w ciągu ostatniej dekady ukształtowała nasze poglądy na komunikację i kulturę. To algorytmy decydują o interakcjach użytkowników z produkowanymi przez nich informacjami. Wskazują na możliwości wyszukiwawcze i zdobywania wiedzy, a stanowiąc sedno ATT determinują komunikowane treści i sposoby ich komunikowania. Jednocześnie utrudniają one transparentność systemów, gdyż dla użytkownika algorytm jest czarną skrzynką; nie wiemy do końca, co powoduje takie a nie inne jego działanie 9 . Wszechobecne komputery i procesy oparte na ich

${ }^{8}$ O jej roli świadczy fakt, że oprogramowanie obecnie stosowanych interfejsów graficznych (ang. graphic user interface, GUI) może obejmować nawet $80 \%$ całego czasu przeznaczonego na oprogramowanie systemu.

${ }^{9}$ Co interesujace, czasem również twórcy algorytmów i oprogramowania nie posiadają takiej wiedzy, gdyż współczesne oprogramowanie, szczególnie w przypadku dużych systemów informacyjnych jest tak skomplikowanym tworem, że nawet jego autorzy przestaja nad nim panować (Badurek, 1999). 
algorytmach wpływają na nasze rozumienie kultury, co stało się powodem powstania terminu „kultura algorytmiczna” (Striphas, 2015, p. 395), w której algorytmy są rozumiane jako socjotechniczna agregacja łącząca w sobie to, co ludzkie i nie-ludzkie, kulturowe i obliczeniowe. Efektem jest automatyzacja kulturowego procesu decyzyjnego i malejąca rola ludzi $\mathrm{w}$ tym procesie.

Algorytmy systemów ATT przygotowują analizy statystyczne, które komunikowane są użytkownikom, także w formie wizualizacji (grafik i wykresów). Jest to forma komunikacji, rodzaj dialogu użytkownika z systemem (autorem algorytmu), jego odpowiedź na informację przekazaną przez użytkownika. Jednocześnie analizy te są podstawą do reakcji użytkownika w sprzężeniu zwrotnym: informacja po przetworzeniu przez algorytm staje się podstawą dla zmian w działaniu (np. w odżywianiu, intensywności ćwiczeń, formułowaniu wyrażenia wyszukiwawczego), co może wpłynąć na treści kolejnej informacji. Jest to również podstawa do tworzenia reprezentacji samego siebie aktualnie i budowy wizerunku lepszego siebie w przyszłości. Prowadzi to także do lepszego zrozumienia samego siebie, własnej cielesności i mentalności oraz ich wpływu na wybór celów życiowych. Jest to więc rodzaj komunikacji z samym soba, chociaż oczywiście niepozbawionej elementów oddziaływania komunikowania społecznego, chociażby przez zastosowanie wzorców społecznych tego, co jest uważane za bycie „lepszym” lub "gorszym”. Warto wspomnieć także o afektywnym oddziaływaniu analiz, szczególnie prezentowanych w formie graficznej. Mogą one być źródłem przyjemności, zapewne wynikającej z bardziej pozytywnej oceny samego siebie (Rooksby et al., 2014, p. 1169), spowodowanej zaspokojeniem indywidualnych potrzeb użytkownika z ukierunkowaniem uwagi na lepszą przyszłość. Taka komunikacja wywołuje poczucie powagi i szacunku u użytkownika, dla którego poziom uzyskiwanych wyników ma już czasem drugorzędne znaczenie.

Systemy ATT zwykle pozwalają użytkownikom na stworzenie relacji i realizację komunikacji z innymi użytkownikami podobnych urządzeń. W takim sensie ATT spełnia funkcje mediów społecznościowych, pozwalając na przyłączanie do sieci, rozpowszechnianie informacji, linkowanie i komentowanie, które są następnie kształtowane przez praktyki komunikacyjne użytkownika. Taki punkt widzenia przybliża praktyki self-trackin$g u$, rozumiane jako działania komunikacyjne, do badań nad komunikacją mediowaną komputerowo (computer-mediated communication, CMC) jako narzędziem socjalizacji. Wówczas komunikacja jest postrzegana głównie jako sposób na osiaganie współpracy i uzgadnianie znaczeń bieżącej sytuacji, na zapewnienie ładu społecznego, dzięki czemu odnajdywany jest sens i przyjemność w przynależności do świata informacyjnego (Carey, 2009). Można więc powiedzieć, że praktyka komunikowania się z innymi implikuje stałe negocjacje tego, co jest odpowiednie, relewantne i ocze- 
kiwane w określonym kontekście świata informacyjnego. Przekazywanie informacji o działaniach self-trackingu, a w szczególności o uzyskiwanych rezultatach, ma wpływ na analizowane praktyki, powodując nawet powstawanie swoistego sprzężenia zwrotnego: komunikowana informacja dociera do innych powodując wzrost motywacji i przekazywanie coraz większych ilości informacji. Grupy komunikujących się użytkowników stają się grupami wsparcia w swoim świecie informacyjnym. Funkcje komunikacyjne self-trackingu $\mathrm{w}$ zakresie rozpowszechniania efektów aktywności odpowiadają zjawisku, który Castells nazywał masową samokomunikacją (Castells, 2007, p. 239), realizowaną poprzez komunikaty zindywidualizowane i skupione treściowo na nadawcy, rozpowszechniane online do potencjalnie masowego odbiorcy. Są one związane z kulturą i technologią społeczeństwa sieci oraz oparte na horyzontalnych sieciach komunikacyjnych, zapewniających komunikację interaktywną w której łączone są treści lokalne z globalnymi w wybranym przedziale czasowym.

Traktowanie praktyk self-trackingu jako komunikacji powoduje podkreślenie roli odbiorców informacji, procesów tworzenia znaczeń oraz środków technicznych i sposobów komunikacji, co można wykorzystać jako podstawę do lepszego zrozumienia funkcjonowania elektronicznej komunikacji naukowej. Według Jacka Andersena i Stine Lomborg (2020, p. 45) otwiera to możliwości bardziej zrównoważonego oglądu sytuacji tej komunikacji, w którym grywalizacja ${ }^{10} \mathrm{i}$ konkurencja łączy się ze współpracą i autorefleksją.

\section{SAMOPOZNANIE I ANALIZA INFORMACJI W OBSZARZE PUBLIKOWANIA NAUKOWEGO}

Mówiąc o samopoznaniu nie mamy na ogół na myśli poznania naukowego, choć oba te procesy poznawcze mają co najmniej jedną cechę wspólną: ich podstawą są operacje na danych i informacji. Głównym celem ruchu QS jest pomoc ludziom w zrozumieniu ich danych, gromadzonych w codziennych czynnościach, zaś jego mottem jest „,styl życia oparty na danych" (Pullar-Stecker, 2014), co w nauce i komunikacji naukowej może być sparafrazowane jako „metoda naukowa oparta na danych i informacji”.

Andersen i Lomborg (2020) proponują nową koncepcję komunikacji naukowej. Według nich może być ona postrzegana jako indywidualne, profesjonalne działanie skierowane do samego siebie. Uległa ona istotnym zmianom w wyniku rozwoju ATT, umożliwiającej samopoznanie i ana-

${ }^{10}$ Grywalizacja (ang. gamification) to zastosowanie elementów i technik gry w kontekstach nie związanych $z$ grami (np. w organizacji informacji). Ma na celu wzrost zaangażowania ludzi, prowadzacy do lepszego rozwiąywania problemów (Hammarfelt, de Rijcke \& Rushforth, 2016). 
lizy informacji dotyczącej funkcjonowania jej użytkowników w świecie nauki. Self-tracking w komunikacji naukowej daje naukowcom możliwości komunikowania się pomiędzy naukowymi światami informacyjnymi, a także samopoznania $\mathrm{w}$ różnej skali i okresach dzięki afordancjom ${ }^{11}$ mediów cyfrowych. Taki punkt widzenia wyraźnie różni się od poglądu na system komunikacyjny, w którym główne możliwości śledzenia wyników aktywności innych i własnych są ograniczone do analizy indeksów cytowań i spisów bibliograficznych wykorzystanych publikacji w artykułach naukowych.

Dla nowych zasad komunikacji ważna jest możliwość indywidualnej prezentacji i budowy tożsamości w społecznościowych platformach dla naukowców. Kim Barbour i David Marshall (2012) wyróżnili pięć głównych form prezentacji online osobowości naukowców: formalna, sieciowa, wszechstronna, dydaktyczna i nieokreślona. Osobowość formalna jest stosunkowo statyczną i nieinteraktywną reprezentacją siebie, która spotykana jest często na instytucjonalnych stronach Web; osobowość sieciowa bardziej jest nakierowana na interakcje, do których dochodzi na blogach lub prywatnych stronach Web; osobowość wszechstronna także zawiera informacje osobowe, a nawet osobiste (rodzina, religia, poglądy polityczne) w samoprezentacji online. Te trzy rodzaje prezentacji przeznaczone są dla szerokiego grona odbiorców, inaczej niż osobowość dydaktyczna, która jest skierowana do określonej grupy studentów, gdzie ważna jest silna interakcja i komunikacja. Osobowość nieokreśloną online posiadają osoby, które nie angażują się w uczestnictwo w nowych mediach. Powoduje to niebezpieczeństwo tworzenia osobowości takiej osoby przez innych, bez jej udziału.

Złożone prezentacje osobowości online naukowców zapewnia rozwój naukowej komunikacji elektronicznej, powstanie i popularyzacja nowych narzędzi komunikowania, takich jak Google Scholar, ResearchGate, LinkedIn $^{12}$ oraz niezależnych wydawców OA (np. PLOS). Spowodował on powstanie i upowszechnienie się nowych, alternatywnych miar oceny jakości publikacji (altmetrics), takich jak "liczba kopiowań”, „liczba wyświetleń", „liczba odczytan", „cytowania na Facebooku”, "cytowania w blogach" itp., traktowanych jako miary aktywności, popularności i prestiżu. Serwisy te funkcjonują w oparciu o obiekty, takie jak rankingi, kolejne poziomy „wtajemniczenia”, nagrody, typowe dla gier. Pozwalają także uzyskać prawie natychmiastową reakcję i gratyfikację, co także jest cechą gier online (Hammarfelt, de Rijcke \& Rushforth, 2016). W ten spo-

${ }^{11}$ Termin afordancje jest stosowany dla opisu sposobów, w jaki środowisko materialne umożliwia określone zachowania (Gibson, 1979, s. 127). Częstym przykładem jest krzesło, które pozwala usiąść.

${ }^{12}$ Według badań Jamali, Niocholasa i Herman (2016) te trzy platformy społecznościowe cieszą się największą popularnością wśród naukowców. 
sób, obok tradycyjnych miar cytowań, w naukowej komunikacji elektronicznej możliwe jest stosowanie zasad samopoznania i analiz informacji indywidualnej na znacznie większą skalę niż poprzednio. Naukowcom, nie mniej niż miłośnikom uprawiania kultury fizycznej, zależy na tych analizach, widzialności $\mathrm{w}$ sieci, zdobywaniu popularności i reputacji (prestiżu) w swoim świecie informacyjnym (Herman \& Nicholas, 2019). Serwisy społecznościowe przeznaczone dla naukowców służą prezentacji i promocji indywidualnych naukowców, co jest cechą systemów QS. Taki system ewaluacji komunikacji naukowej umożliwia włączenie do niego samooceny i analiz aktywności poszczególnych naukowców.

Można wyróżnić przynajmniej dwa kierunki stosowania self-trackingu w odniesieniu do publikowania naukowego. Pierwszy z nich to wykorzystanie analiz oferowanych przez serwisy społecznościowe wspomagające naukę, takie jak Google Scholar lub ResearchGate. Podstawą tych analiz jest działalność publikacyjna użytkowników, obudowana jednak licznymi usługami dodatkowymi. Systemy te są określane jako serwisy społecznościowe, które wykorzystują standardowe cechy mediów społecznościowych oferując możliwości tworzenia, promowania i pomiarów reputacji (Jamali, Nicholas \& Herman, 2016, p. 37). Zwykle dokonuje się tego dzięki mechanizmom ułatwiającym prowadzenie działalności naukowej w ogóle i publikacyjnej w szczególności oraz zapewnieniu możliwości pomiaru, prezentacji i porównywania jakości lub poziomu wpływu dla tej działalności, a także możliwości oceny w formie punktowania, dostępnej dla całej społeczności świata informacyjnego skupionego wokół platformy. Oba te serwisy (i inne podobne) udostępniają analizy indywidualnej aktywności naukowców, co umożliwia m.in. ocenę własnej działalności w dłuższych okresach oraz dokonywanie w niej korekt w celu uzyskania lepszych wyników. Należy jednak zauważyć, że starsze serwisy, takie jak Google Scholar, różnią się od nowszych, takich jak ResearchGate. Te ostatnie dają możliwości budowy relacji służących konstrukcji światów informacyjnych naukowców oraz oferują miary alternatywne reputacji, inne niż ilość publikacji i/lub cytowań. ResearchGate daje bardzo obszerne możliwości budowy własnej tożsamości i profilu naukowego oraz komunikacji naukowej. Funkcjonalności ResearchGate pozwalają na komunikowanie się z systemem (algorytmem), z samym sobą i z innymi naukowcami zainteresowanymi publikacjami i współpracą. System (jego algorytm), na podstawie informacji przekazanych podczas tworzenia profilu oraz bieżących aktywności użytkownika prowadzi z nim bogatą korespondencję. Na podstawie rejestrowanych zdarzeń, związanych z materiałami udostępnionymi przez użytkownika (głównie publikacjami, ale także projektami itp.), przysyłane są zawiadomienia (w formie listu gratulacyjnego) o tzw. kamieniach milowych (ang. milestones), np. kolejnych dziesięciu czytelnikach określonego tekstu. System informuje o nowych publika- 
cjach i projektach, które mogą zainteresować użytkownika. Prezentowane są także oferty pracy. Dla zapewnienia poprawnych metadanych o publikacjach przysyłane są także prośby o potwierdzenie autorstwa własnych i obcych prac.

Nie mniej obszerny jest zestaw informacji udostępnianych użytkownikowi, na podstawie których może on dokonywać analiz swoich dotychczasowych osiągnięć i ewentualnych korekt w swojej dotychczasowej strategii publikacyjnej. Przede wszystkim ResearchGate oblicza i podaje dla każdego użytkownika, jako jawną informację tzw. RG score, punktację obliczaną na podstawie aktywności użytkownika. Choć algorytm jej tworzenia nie jest znany (publikacje stanowią niewątpliwie jego podstawę) i jest często modyfikowany, można dzięki temu wskaźnikowi nie tylko oceniać własne postępy, ale także porównywać się z innymi użytkownikami za pomocą jednej wartości liczbowej. Ta druga funkcja jest ułatwiona poprzez udostępnianie tzw. percentile, wskazującego na miejsce wskaźnika użytkownika w stosunku do innych użytkowników (twój RG score jest wyższy niż dla $x \%$ wszystkich użytkowników). Wskazanie na publikacje najwyżej cytowane pozwala także na zorientowanie się $\mathrm{w}$ popularności zagadnień badawczych. Cytowania są używane również do wyliczania wskaźnika h-index, chociaż ResearchGate robi to znacznie mniej wiarygodnie niż inne serwisy, np. Google Scholar. Innym wskaźnikiem reputacji (oprócz wymienionych) jest także liczba osób śledzących profil (ang. followers).

ResearchGate jest serwisem, który umożliwia również konstruowanie światów informacyjnych naukowców o podobnych zainteresowaniach. Służą temu narzędzia ułatwiające komunikację pomiędzy użytkownikami serwisu. Już sam profil użytkownika, tworzony na początku aktywności w serwisie, jest zestawem informacji, która powinna umożliwić podejmowanie decyzji o bliższym kontakcie. Podawane są w nim m.in. dyscypliny badawcze i umiejętności użytkownika. Nie mniej przydatny jest także wykaz publikacji z pełnymi tekstami udostępnianymi przez użytkownika. Jednak istnieją także możliwości bardziej bezpośrednich kontaktów, np. przysyłanie własnych pytań i udzielanie odpowiedzi na pytania innych użytkowników. System informuje o przysłanym pytaniu tych użytkowników, których uzna za potencjalnie zainteresowanych. Odpowiedzi są oceniane i wpływają na $R G$ score. Możliwe jest także przysyłanie żądań (ang. request) do wybranych użytkowników, np. z prośbą o kopię ich publikacji lub zaopiniowanie własnej pracy.

Drugi kierunek stosowania self-tracking $u$ w obszarze publikowania naukowego możliwy jest dzięki zachodzącym tu zmianom, szczególnie widocznym w publikowaniu OA w połączeniu ze stosowaniem miar alternatywnych. Bardzo dobrym przykładem jest działalność prekursora w tym zakresie, wydawcy PLOS. Pomimo tego, że wydawcy tytułów czasopism 
PLOS są bardzo otwarci na wszelkie nowe afordancje środowiska elektronicznego, to nawet tam artykuł naukowy jako forma tekstowa nie uległ drastycznym zmianom (Casper, 2016, p. 95). Artykuły nadal tworzone są według tych samych stylistycznych i formalnych wzorców gatunkowych (np. struktura IMRaD), które obowiązują od dziesięcioleci (Mehlenbacher \& Mehlenbacher, 2019, p. 45). Nadal więc aktualne są w tym zakresie opinie Johna Owena (2007), który pisał o „kapsułowaniu” artykułu naukowego, rozumiejąc przez to stabilność formy i treści artykułu nawet po przeniesieniu do nowego, elektronicznego medium. Zasadniczym zmianom uległy natomiast sposoby posługiwania się tymi tekstami, co bardzo istotnie wpływa na kierunki ewolucji czasopism naukowych (Gross \& Harmon, 2016, p. 50). Zmianie nie uległ więc tekst artykułu naukowego, ale coś, co można nazwać paratekstem (Genette, 1997, p. 7), którego główną funkcją jest ułatwienie korzystania z tekstu (artykułu), poprzez wskazanie jego cech indywidualnych i relacji intertekstualnych.

Wydawcy PLOS z założenia opierają ocenę artykułu na innych miarach niż Impact Factor, chociaż cytowania również brane są pod uwagę. Na stronie opisującej cechy czasopisma PLOS ONE można przeczytać, że „zamiast polegać wyłącznie na miarach poziomu czasopisma, takich jak Impact Factor, PLOS oferuje zindywidualizowane miary poziomu naukowego artykułu, odzwierciedlające stopień przeglądania tekstu, kopiowań, rozpowszechnienia w mediach społecznościowych oraz cytowań opublikowanego artykułu dostarczane w czasie rzeczywistym, co pozwala unaocznić naukowcom wielkość wpływu ich badań" (PLOS ONE, 2019). Miary te udostępniane są autorowi i czytelnikowi wraz z tekstem artykułu.

Rzeczywiście, przejście na stronę dowolnego artykułu obrazuje bogactwo wielu miar, które wyliczane są dla niego indywidualnie i prezentowane wraz z ich zmianami w czasie. Dzięki temu można śledzić rozwój zainteresowania poszczególnymi artykułami, a co za tym idzie, obserwować tę część procesów komunikacji, które są z nimi związane, nawet, jeśli informacja ta nie jest dziełem autora artykułu, ale odzwierciedla zaangażowanie czytelników. Jest to więc komunikacja autora artykułu z samym soba, która umożliwia jednocześnie komunikację autora z innymi użytkownikami (czytelnikami). Dostępne informacje paratekstowe w formie prezentowanych miar przynajmniej częściowo określają poziom rozpoznawalności artykułu online i, co za tym idzie, oczekiwań w stosunku do niego kolejnych potencjalnych czytelników. Innymi słowy, afordancje związane z medium elektronicznym kształtują gatunek artykułu naukowego (Andersen \& Lomborg, 2020, p. 48).

Zaraz po wyświetleniu strony artykułu pojawia się pierwsza informacja dotycząca miar dla tego tekstu. Na wysokości tytułu artykułu, a więc na eksponowanym miejscu, podawana jest informacja o liczbie przeglądań (view), kopiowań (save), cytowań (citation) i poziomu rozpowszechnienia 
informacji w mediach społecznościowych (share). Po wybraniu zakładki Metrics ukazuje się dokładniejsza informacja. Przeglądania rozbite są na liczbę wyświetleń strony html oraz kopiowań tekstu w formatach PDF i XML. Dołączany jest też wykres przeglądań kumulatywnie w czasie. Ilość cytowań rozbita jest na zliczające je serwisy, na przykład Scopus, CrossRef i Google Scholar. Prezentowana jest ilość kopiowań do serwisów bibliograficznych online, takich jak Mendeley i CiteULike oraz podawana jest informacja o dyskusjach nt. artykułu, prowadzonych na blogach (głównie naukowych) i mediach społecznościowych (Twitter, Facebook, Reddit). Odrębnie prezentowane są komentarze czytelników do artykułu.

Wszystkie te miary łącznie wskazują na zdolność autora i jego artykułu do komunikowania z systemem ATT w obrębie obszerniejszej infrastruktury generującej i rozpowszechniającej miary. Oznacza to, że prezentacja miar nie służy komunikacji wyłącznie pomiędzy naukowcami, ale także umożliwia komunikację z systemem. Udostępnianie wartości miar, obliczanych dla artykułu, stwarza także możliwości komunikowania się z samym sobą ${ }^{13}$. Każdy autor artykułu może dzięki nim monitorować, analizować i śledzić odbiór swego artykułu w systemie i stosować tę informację dla doskonalenia swojej przyszłej aktywności. Podobnie, jak w aplikacjach do self-trackingu, nie może on zmienić uzyskanych wyników; możliwe jest tylko lepsze dostosowanie się w przyszłości do sposobu funkcjonowania systemu publikowania naukowego. Dzięki miarom możliwe jest także porównywanie osiągnięć autora artykułu z innymi tekstami, w tym pisanymi przez kolegów i potencjalnych konkurentów. W efekcie komunikacja z samym sobą zmienia naukowca w jednostkę śledzącą własne, skwantyfikowane rezultaty, jednocześnie stymulując komunikację z innymi. Wpływa to na intensyfikację walki konkurencyjnej w systemie komunikacji naukowej.

W uzupełnieniu roli, jaką przedstawione serwisy, zarówno typu ResearchGate, jak i PLOS odgrywają w konstruowaniu tożsamości autorów i czytelników (zamieniających się nieustannie rolami), można także znaleźć związki pomiędzy stałą potrzebą samodoskonalenia z jednej strony, a uleganiem pokusie udziału w grze o dostarczenie jak najbardziej poczytnego, „przełomowego" produktu, z drugiej. Prawdą jest, że w działalności naukowej rzadko można spodziewać się natychmiastowej gratyfikacji, typowej dla gier. Jednak gry i interakcje w mediach społecznościowych podobne są przez "kuszenie” użytkowników w obu sytuacjach do użycia wbudowanych mechanizmów stymulujących chęć dążenia do bycia lepszym i posiadania więcej (wyższego poziomu w grze, więcej „,kamieni

${ }^{13} \mathrm{Na}$ podobnej zasadzie jak podwyższone tętno (problem somatyczny) komunikuje ćwiczącemu np. potrzebę odpoczynku (komunikacja z samym soba), tak samo spadek cytowań (problem mentalny) komunikuje naukowcowi np. potrzebę zmiany zakresu badań (także komunikacja $z$ samym soba). 
milowych", cytowań, śledzących w portalu naukowym). Samopoznanie i analizy informacji indywidualnej w komunikacji naukowej, realizowane za pomocą kodyfikacji komunikacji z użyciem miar wpływu, pozwalają na traktowanie komunikacji naukowej jako swoistej gry, w której monitorowana jest własna aktywność oraz umożliwiana socjalizacja poprzez tworzenie światów informacyjnych skupiających współpracujących specjalistów. Takie usytuowanie pracownika nauki może powodować zjawiska negatywne, jak to, że na jego pozycję mniejszy wpływ może mieć udział w rozwoju wiedzy, a większy zdolność do korzystnego manipulowania miarami w procesach komunikacji naukowej z wykorzystaniem sieci społecznościowych.

\section{SAMOPOZNANIE I ANALIZA INFORMACJI WSPOMAGANE BIBLIOTECZNYM SYSTEMEM KOMPUTEROWYM}

W związku z upowszechnianiem się narzędzi ATT w wielu obszarach komunikacji naukowej, powstaje pytanie, w jaki sposób możliwe jest wykorzystanie ideologii samopoznania (QS) i analiz informacji indywidualnej (self-tracking) w działalności informacyjnej prowadzonej przez biblioteki za pomocą zintegrowanych systemów komputerowych. Ze względu na ich funkcje, przede wszystkim statystyczne oraz gromadzenia i udostępniania różnego rodzaju metadanych (w tym głównie opisowych i administracyjnych), możliwe jest przyjęcie takiego punktu widzenia, w którym komputerowy system biblioteczny traktowany jest jako ATT, stanowiący źródło informacji o jego użytkownikach (zarówno pracownikach ${ }^{14}$, jak i użytkownikach końcowych). Informacja ta może być udostępniana obu tym grupom (oraz ich podgrupom) w różnym zakresie, co jest praktykowane $\mathrm{w}$ formie np. stosowania systemu haseł, dających dostęp do różnych interfejsów, udostępniających różne funkcjonalności określonych modułów systemów bibliotecznych wybranym grupom użytkowników.

Analizy, które odbywają się z udziałem pracowników biblioteki, mogą być realizowane na podstawie informacji pochodzących z uzyskiwanych danych statystycznych (Szmigielska, 2011). Istotnym ich źródłem są zintegrowane systemy biblioteczne, często oferujące całe zestawy danych, a nawet odrębne moduły pozwalające całościowo zobrazować działanie komunikacyjne systemu. Dane statystyczne były ważne dla budowy strategii normalizacyjnych, pojawiających się już w XIX w., ponieważ czyniły one działania osób i bibliotek bardziej widocznymi i podatnymi

${ }^{14}$ Zauważmy, że grupa pracowników biblioteki jako użytkowników systemu bibliotecznego, z punktu widzenia możliwości analizy danych także nie jest grupa jednolita, gdyż np. poszczególni pracownicy maja nadane różne uprawnienia do pracy w systemie. W szczególności należałoby tu wyróżnić administratorów systemów bibliotecznych, zwykle posiadających największe uprawnienia. 
na techniki zarządcze oraz służyły konstruowaniu norm, na podstawie których możliwe stawały się analizy porównawcze. Statystyki i inne formy kwantyfikacji działań, koncepcji i funkcji użytkowników i ich grup są tym bardziej niezbędne dla współczesnych strategii samopoznania $\mathrm{w}$ systemach informacyjnych. Istniejące standardy i quasi-standardy $\mathrm{w}$ tym zakresie prezentują możliwości analiz stanowiących podstawę doskonalenia postępowania. Dane statystyczne, wyprowadzone z systemów bibliotecznych, pozwalają dostrzec aspekty istnienia jednostek i grup, które w inny sposób nie są dostrzegalne, gdyż statystyki mogą służyć powiązaniu ze sobą wielu informacji pochodzących z różnych źródeł. W ten sposób użytkownicy współtworzą wiele agregacji, którymi można manipulować i je modyfikować w zależności od rozpatrywanego lub poszukiwanego aspektu.

Metadane, w szczególności opisowe, tworzone w module katalogowania, prezentowane są w bibliotecznym OPAC. Użytkownicy zyskują istotne narzędzie analityczne ATT $w$ funkcjach OPAC wzorowanego na działaniu mediów społecznościowych (OPAC 2.0). Pozwala on na zwiększenie poziomu partycypacji użytkowników oraz intensyfikację komunikacji z systemem (zarówno jego projektantem, jak i bibliotekarzem) oraz oferuje możliwości komunikowania się w obrębie społeczności użytkowników. Warto zwrócić także uwagę na fakt, że współczesne OPAC (podobnie jak inne bibliograficzne bazy danych) konstruowane są w sposób pozwalający na samodzielne, indywidualne zdobywanie informacji, bez potrzeby szukania pomocy u kogokolwiek. Taki indywidualny styl działania jest typowy dla narzędzi self-trackingu.

Taki punkt widzenia nazwać można węższym; możliwe jest także bardziej ogólne, szersze spojrzenie, gdzie system biblioteczny traktowany jest jako źródło informacji, do której dostęp powoduje zmiany mentalne (rozwój wiedzy) pozwalające na bardziej świadome sterowanie swoim życiem i podejmowanie właściwych decyzji o kierunkach zmian dla jego doskonalenia. Ten punkt widzenia uwzględnia wcześniej już przedstawiony fakt, że QS jest procesem poznawczym i formą tworzenia wiedzy. Biblioteki w ogóle, ale także poprzez stosowanie systemów komputerowych, wspomagają takie procesy, działając chociażby jako instytucje pamięci. Taki punkt widzenia uwzględniony został w normie PN-ISO 16439 (2019, s. 21), w której przedstawiany jest wpływ ${ }^{15}$ bibliotek m.in. na jednostki, oznaczający zmiany umiejętności i kompetencji, postaw i zachowań, większe sukcesy w zakresie badań, studiów lub kariery oraz osobisty dobrostan. Self-tracking biblioteczny może być traktowany jako strategia umysłowa,

${ }^{15}$ Wpływ określony został natomiast jako oddziaływanie bibliotek i ich usług na jednostkę i/lub społeczeństwo. Opisany w dalszej części artykułu self-tracking wspierany bibliotecznym systemem komputerowym może być traktowany jako ilościowa metoda badania wpływu biblioteki. 
w której jednostki zajmują się tworzeniem, gromadzeniem i analizą zapisów informacji związanej z ich aktywnościami życiowymi, bez względu na obszar zastosowań. Jednym z takich obszarów związanych z działalnością naukową jest publikowanie, opisane w poprzedniej części artyku$ł u$, innym jest tworzenie, organizacja i wyszukiwanie (meta)informacji, realizowane $\mathrm{w}$ zintegrowanych systemach bibliotecznych, przedstawione w tej części artykułu.

Biblioteka jest miejscem stosowania wielu technologii informacyjnych, które mogą być traktowane jako ATT. Technologie te, według poglądów nazywanych nowym materializmem ${ }^{16}, \mathrm{w}$ połączeniu z ich użytkownikami tworzą agregacje techno-ludzkie, w których afordancje technologii mogą wywoływać reakcje ludzi w pewien określony i zrozumiały sposób. Jednak afordancje te nie są aktywowane, dopóki nie dochodzi do współdziałania z ludzkim użytkownikiem. Ludzie mogą używać technologii, w tym informacyjnych, włączając je w swoje codzienne zachowania poprzez reakcję na te afordancje i zaangażowanie w nie. Możliwych jest wiele reakcji na pojawiające się afordancje: improwizacja, przeciwdziałanie lub odkrywanie kolejnych, nowych. Ludzie i technologie współpracują jako część ciągłego stawania się artefaktów i ich ucieleśnienia. Agregacje te nigdy nie są zamknięte ani zakończone, zawsze są odtwarzane na nowo (Lupton, 2020).

Podejście to może być zilustrowane przez sytuację systemu bibliotecznego jako narzędzia self-trackingu. Powstają wówczas agregacje informacji cyfrowej, tworzone w związkach ludzi z ATT, do których zaliczyć można także zintegrowane systemy biblioteczne. Istotną rolę w tej sytuacji komunikacyjnej odgrywa doświadczenie pracowników bibliotek w obsłudze nowych technologii informacyjnych. Przykładem może być zastosowanie technologii mobilnych, w szczególności wszelkiego rodzaju czytników tekstów, stanowiących podstawę oferowanych nowych usług bibliotecznych. Współpracują oni (ludzie i technologie) w celu tworzenia nowej informacji, która może być wielokrotnie stosowana (gromadzona, wyszukiwana, wykorzystywana) i konfigurowana. Informacja tworzona podczas bibliotecznego self-trackingu dotyczy ludzi i jest dla nich przeznaczona. Ludzie używają swojej cielesności (zmysłów) do konfigurowania i interpretowania informacji, współdziałając z sensorami cyfrowymi. Takie podejście wychodzi daleko poza rozumienie kompetencji informacyjnych (ang. information literacy) stosowane w informatologii, gdyż poza przetwarzaniem poznawczym uwzględnia rolę cielesności oraz umiesz-

${ }^{16} \mathrm{~W}$ nowym materializmie wskazuje się na materialną naturę świata i wszystkiego, co $\mathrm{w}$ nim istnieje, społecznego i naturalnego. Materia świata jest bardzo zmienna, wyłania się on stale poprzez ciagi interaktywnych i efektywnych wydarzeń/agregacji ludzi, innych organizmów, rzeczy materialnych, przestrzeni, całego środowiska podlegającego siłom materialnym, takim jak czas i grawitacja (Fox \& Alldred, 2019). 
cza procesy nadawania sensu $\mathrm{w}$ przestrzeni pomiędzy użytkownikami i systemem bibliotecznym.

Agregacje, których składnikiem jest indywidualna informacja cyfrowa, posiadają własne życie społeczne, gdyż cyrkulują w obrębie ekonomiki informacji cyfrowej, gdzie są dostępne i wykorzystywane przez wielu potencjalnych agentów indywidualnych i instytucjonalnych. Są one także żywe w takim sensie, że dotyczą one elementów ludzkiego życia oraz posiadają wartość jako coraz bardziej utowarowione obiekty w ekonomice informacji cyfrowej. Takie agregacje są wciąż zmienne, dynamiczne, reagujące na nowe bodźce i interpretacje. Ludzie żyją i wspólnie ewoluują z otaczającą ich informacją reagując na siebie nawzajem w sposób synergiczny $\mathrm{w}$ procesach tworzenia świata informacyjnego. Praktyki self-trackingu w systemie bibliotecznym można rozumieć jako współdziałanie dwóch takich systemów: ciała (użytkownika) gromadzącego informację i wiedzę oraz zasobu informacyjnego systemu bibliotecznego jako narzędzia wspomagającego poszczególne części lub funkcje ciała (nas interesować będą szczególnie funkcje umysłowe). Uznana za użyteczna, informacja pozyskana z systemu bibliotecznego jest kombinowana $\mathrm{z}$ wiedzą zgromadzoną w ludzkim ciele (głównie w mózgu), tworząc nową agregację. Szeroko rozumiani użytkownicy bibliotek są uważani za twórców lub odbiorców informacji indywidualnej, która jest mediowana przy pomocy ATT i z powrotem im prezentowana $\mathrm{w}$ przetworzonej postaci do dalszych analiz. Stają się oni częścią systemu bibliotecznego (i vice versa).

Analizy informacji ilościowej $\mathrm{w}$ bibliotekach podzielić można ze względu na to, przez kogo są prowadzone. Można wyróżnić dwie zasadnicze grupy osób zainteresowanych tego rodzaju self-trackingiem: pracowników bibliotek (bibliotekarzy i administratorów systemu) oraz ich klientów (użytkowników). W obu przypadkach informacja ta może służyć komunikacji trzech rodzajów: z zintegrowanym systemem bibliotecznym, z samym sobą (dotyczy bibliotekarza lub użytkownika końcowego) oraz z innymi (komunikacja bibliotekarz-bibliotekarz, bibliotekarz-użytkownik i użytkownik-użytkownik). Obie wymienione zmienne: grupa użytkowników i rodzaj komunikacji tworzą matrycę, krótko opisaną poniżej.

Komunikacja z systemem - pracownicy bibliotek. Komunikacja taka następuje w przypadku, gdy system wysyła utworzony przez algorytm komunikat, zawierający dane ilościowe, powodujący określone zachowanie bibliotekarza. Taki komunikat może zawierać np. informację o kończeniu się środków finansowych na którymś z kont w module gromadzenia. Wówczas, na podstawie informacji o wielkości pozostałej kwoty, bibliotekarz może podjąć decyzję o dalszym wydatkowaniu istniejących jeszcze funduszy lub zasileniu konta zewnętrznymi funduszami. Wybór sposobu postępowania zależy m.in. od założonych celów działania (np. polityki gromadzenia zbiorów) i wiedzy bibliotekarza o poziomie ich realizacji. 
Podobna sytuacja komunikacyjna występuje w przypadku, gdy system biblioteczny monituje bibliotekarza o przekroczeniu terminu dostawy zeszytu prenumerowanego czasopisma o określoną ilość czasu. Na podstawie tej informacji bibliotekarz może podjąć działania $\mathrm{w}$ zależności od sytuacji: np. monitować dostawcę lub zrezygnować z numeru czasopisma, który się nie ukazał. W obu przypadkach działania te pociągają za sobą określone konsekwencje, które stwarzają nową sytuację wymagającą dalszego monitorowania.

Komunikacja z systemem - użytkownicy końcowi. Użytkownicy końcowi (czytelnicy) także otrzymują od systemu informacje, służące modyfikacji ich działań. Tak jest np. w przypadku, gdy użytkownik, wprowadzając zapytanie wyszukiwawcze, popełni błąd literowy. Wówczas system wysyła komunikat o zerowym wyniku wyszukiwania oraz może proponować korektę błędu pytając: "Czy chodziło ci o...”. Użytkownik może skorzystać z podpowiedzi i kontynuować wyszukiwanie lub stwierdzić, że biblioteka nie posiada interesującej go publikacji i szukać jej w innej bibliotece. Powyszukaniu interesującej pozycji i próbiejej zamówienia użytkownik także może otrzymać komunikaty systemowe, informujące np. o liczbie pozycji przeterminowanych na jego koncie czytelniczym i liczbie dni po terminie zwrotu albo o wyczerpaniu limitu wypożyczeń przewidzianego dla określonej grupy czytelników. Ta sytuacja komunikacyjna również wymaga modyfikacji zachowania ze strony klienta biblioteki: zwrotu odpowiednich, wcześniej wypożyczonych pozycji lub zaniechania prób kolejnych wypożyczeń.

Przedstawione przykłady świadczą o tym, że w stosunku do użytkowników w bibliotekach stosowany jest swego rodzaju ranking, którego wartości powstają poza systemem informacyjnym. Chodzi o uprawnienia użytkownika, różnicowane głównie ze względu na zajmowane przez niego stanowisko lub pełnioną funkcję - inne uprawnienia przyznaje się np. studentowi, a inne pracownikowi naukowemu. Ta informacja jakościowa jest komunikowana systemowi informacyjnemu poprzez kwantyfikację miar ilościowych; kategorii użytkownika odpowiada na przykład dozwolona liczba wypożyczonych pozycji, okres wypożyczenia itp. Pozycja $\mathrm{w}$ tym rankingu jest jednym $\mathrm{z}$ elementów postrzegania samego siebie przez użytkownika biblioteki w kontekście systemu bibliotecznego.

Komunikacja z samym sobą - pracownicy bibliotek. Taka komunikacja zachodzi, gdy bibliotekarz, inicjując ten proces, uzyskuje z ATT informację, na podstawie której podejmuje decyzje o działaniu. Może on na przykład uzyskać od systemu informację o liczbie skatalogowanych książek (lub innego rodzaju pozycji) dziennie, co może wpłynąć na sposób jego organizacji pracy. Wydaje się, że tego typu zestawienia statystyczne mogą być szczególnie interesujące dla kadry kierowniczej. Self-tracking może także wspomagać politykę gromadzenia zbiorów. System biblioteczny na 
żądanie bibliotekarza dostarcza np. danych o liczbie wypożyczeń dzieła (tytułu) i egzemplarzy dzieła w wybranym okresie. Dane te służą podejmowaniu decyzji o nowych zakupach pozycji cieszących się dużym zainteresowaniem i wycofywaniu egzemplarzy zaczytanych. Można te procesy rozumieć jako konwersję procesów bibliotecznych w reprezentujące je strumienie danych i ponowną ich konwersję w kolejne działania.

Komunikacja z samym sobą - użytkownicy końcowi. Czytelnicy komunikują się głównie na podstawie danych udostępnianych przez OPAC biblioteki. Podstawową informacją otrzymywaną podczas wyszukiwania w systemie bibliotecznym jest liczba wyszukanych pozycji. Pozwala ona na podejmowanie decyzji o dalszych działaniach, np. przeglądaniu wyników lub modyfikacji zapytania. Oferowane są dane mogące służyć kwantyfikacji i analizom, jak: rankingi wyników wyszukiwania według relewancji, $\mathrm{w}$ tym pobieranych z Amazona, grupowanie wyników (fasetyzacja) według m.in. takich kryteriów, jak rok i gatunek publikacji, prezentacja liczby wyszukanych pozycji w zewnętrznych źródłach, na przykład komercyjnych bazach danych. Użytkownik może zawęzić (filtrować) wyniki wyszukiwania wybierając terminy z faset słów kluczowych, haseł przedmiotowych, symboli klasyfikacji, gatunków dokumentów lub formatów (druk, online) na podstawie informacji o liczbie pozycji zaindeksowanych terminem wybranym z fasety (Skórka, 2014, s. 104). Podobnie traktowane mogą być dane z kont czytelniczych, wskazujące na liczbę i rodzaj wypożyczanych pozycji. Dla ułatwienia analiz dane te mogłyby być prezentowane $\mathrm{w}$ formie graficznej, co jest typowe dla self-trackingu (Ruckenstein, 2014, p. 68). Takie działania oznaczają modyfikację postępowania użytkownika na podstawie danych ilościowych, pozyskiwanych z systemu.

Systemy biblioteczne są częścią większego systemu komunikacji naukowej, stąd informacja gromadzona i analizowana w systemie bibliotecznym jest przynajmniej częściowo zbieżna z informacją pochodzącą z innych systemów. Systemy biblioteczne są jedną z dróg dystrybucji danych self-trackingu, powstających w innych częściach systemu komunikacji naukowej. Na przykład wartości miar użyteczności, takie jak IF lub altmetrics tworzone są przez twórców baz danych i wydawców czasopism, ale komunikowane użytkownikom między innymi poprzez strony bibliotek prenumerujących czasopisma i kupujących dostęp do baz danych. W ten sposób biblioteka staje się dla swoich użytkowników centrum danych self-trackingu.

Komunikacja $\mathrm{z}$ innymi - bibliotekarze z bibliotekarzami. Komunikacja tego rodzaju może przebiegać pomiędzy bibliotekarzami tej samej biblioteki lub różnych bibliotek. Dane statystyczne dotyczące wydajności pracy, o których wcześniej była mowa, mogą służyć do analizy własnych zachowań i/lub do porównań wydajności pracowników. Podobnie wy- 
korzystywane mogą być dane dotyczące ilości popełnianych błędów, np. w katalogowaniu. Służą one zmianom zachowań, których celem jest zwiększenie wydajności i wyeliminowanie błędów, co jest typowe dla self -trackingu w miejscu pracy. Takie samo znaczenie mają te dane gromadzone w szerszym kontekście - mogą one służyć porównaniom pomiędzy wieloma bibliotekami. Do tych m.in. celów konstruowane są wskaźniki funkcjonalności bibliotek (por. PN-ISO 11620). O wadze tych działań świadczą projekty, realizowane przez polskich bibliotekarzy: AFB, AFBN, AFBE, AFBP, koordynowane przez SBP. Taka komunikacja, stanowiąca podstawę współpracy, pozwala na dokonywanie uzgodnień na drodze wielostronnych negocjacji, właściwych i oczekiwanych form komunikacji w systemie bibliotecznym, realizowanych pomiędzy bibliotekarzami. Stwarza to z jednej strony poczucie wspólnoty zawodowej, a z drugiej otwiera możliwości współzawodnictwa.

Komunikacja z innymi - bibliotekarze z użytkownikami. Ten rodzaj komunikacji najmniej wspomagany jest przez system komputerowy biblioteki. Częściowo jest ona przenoszona do innych miejsc w sieci, na przykład na biblioteczne konta Facebook, gdzie użytkownicy mają możliwość polubić i komentować poszczególne posty dotyczące aktywności biblioteki, tworzone przez bibliotekarzy. W ten sposób tworzona jest sieć społecznościowa, w której bibliotekarze budują świadomość swoich celów i praktyk związanych z działalnością informacyjną. Facebook może także służyć do prowadzenia badań satysfakcji użytkowników. Taka komunikacja na temat dostępnych usług i ogólnie oferty bibliotecznej, realizowana w ścisłym związku z funkcjami systemu bibliotecznego pozwala na uzyskanie sprzężenia zwrotnego, typowego dla self-trackingu, służącego doskonaleniu działań bibliotecznych. Celem jest tu oczywiście zachęcanie do korzystania z usług biblioteki, ale jednocześnie sprzężenie zwrotne oznacza, że powstała grupa osób zainteresowanych stymuluje kontynuację i rozwój tej działalności. Aktywność taka podobna jest do wspomnianej wcześniej masowej samo-komunikacji opisywanej przez Castellsa. Różnica w stosunku do typowej komunikacji z innymi w self-trackingu polega na większym zróżnicowaniu ról komunikujących się stron: bibliotekarze występują raczej w roli ekspertów, użytkownicy są klientami.

Dzięki funkcjonowaniu systemów bibliotecznych istnieje bardzo duża możliwość śledzenia działań użytkowników w systemie, co powinno być wykorzystane do doskonalenia oferowanych usług. Śledząc logi transakcji możemy na przykład określić sposoby konstruowania zapytań przez użytkowników, w tym poziom stosowania wyszukiwania złożonego i prostego (wpływ na projektowanie systemu) oraz najczęściej stosowane terminy wyszukiwawcze (wpływ na politykę gromadzenia zbiorów).

Komunikacja z innymi - użytkownicy z użytkownikami. Wydaje się, że do tego sposobu komunikacji systemy biblioteczne są także słabo 
przygotowane. Niektóre systemy przejmują podstawowe funkcjonalności z serwisów społecznościowych. Część współczesnych OPAC umożliwia analizy oparte na danych wprowadzanych przez użytkowników: punktowaniu, komentowaniu i tagowaniu (Wilson, 2007). Informacja ta, komunikowana innym użytkownikom, może im pomóc w ocenie przydatności dokumentu lub innych elementów systemu, a sam system nabiera cech typowych dla grywalizacji (Wójcik, 2020, s. 45). Dodatkowo umożliwia konstruowanie wspólnego gruntu, społecznie uzgodnionego rozumienia bibliotecznej sytuacji komunikacyjnej i uprawnionych sposobów działania w niej agregacji techno-ludzkich.

\section{ZAKOŃCZENIE}

Komunikacja naukowa w środowisku sieci rozległych ulega stałej ewolucji. Nowe aplikacje wspomagające tę komunikację, jak ResearchGate i Google Scholar pozwalają nie tylko na monitorowanie aktywności naukowca, ale także na tworzenie jego wizerunku i pozycji w wielu światach informacyjnych, których jest członkiem. W portalach tych stosowane są miary, które pozwalają na odgrywanie nowych ról tekstom publikacji naukowych przez ich obudowanie paratekstem, odzwierciedlającym relacje w systemie społecznym nauki. System ten wciąż służy tworzeniu nowej, certyfikowanej wiedzy, ale jednocześnie staje się on systemem umożliwiającym samopoznanie i analizy informacji indywidualnej. Te praktyki z kolei pozwalają na traktowanie komunikacji naukowej jako pewnego rodzaju gry, w której jednostki monitorują efekty swoich działań oraz wchodzą w interakcje ze światem informacyjnym swojej dyscypliny. W rezultacie ewaluacja badań naukowych w coraz większym stopniu opiera się na systemie reputacji, ocenianej na podstawie ilościowych wskaźników indywidualnej produktywności (Chan, Johns \& Moses, 2018, p. 178). Jest to przyczyną indywidualizacji w nauce: buduje kulturę raczej konkurencji niż współpracy oraz powoduje wyłanianie „celebrytów" życia naukowego (Driessen, 2012).

Opisane zmiany, wskazujące na innowacyjność komunikacji naukowej (Zhai, Ding \& Wang, 2018), umożliwione zostały przez nowe technologie, jednak ich istnienie nie jest warunkiem wystarczającym do rozwoju praktyk samopoznania. Ważniejsze jest ludzkie doświadczenie gromadzone w środowisku, na przykład w świecie komunikacji naukowej, które jest wspomagane dostępną technologią (Yoo, 2010, p. 218), co łącznie powoduje tworzenie agregacji techno-ludzkich. Praktyki QS działają pomiędzy użytkownikiem informacji i technologia, dzięki czemu mogą pełnić funkcję mediacyjna, wspomagając zdobywanie doświadczeń w środowisku informacyjnym. Technologia jest stosowana $w$ celu rejestrowania, indeksowania i analiz doświadczeń użytkownika, w związku z czym jest bar- 
dziej ich częścią niż zewnętrznym narzędziem organizacji doświadczanej rzeczywistości.

Biblioteki, a szczególnie ich systemy komputerowe, traktowane jako ATT, stanowią część tej nowej perspektywy komunikacji naukowej. W tym zakresie współdziałają ze sobą dawne praktyki gromadzenia i przetwarzania danych statystycznych z nowymi narzędziami systemów społecznościowych. W tych sytuacjach self-tracking może być rozumiany jako sposób na osiągnięcie zmiany behawioralnej w grupie celowej poprzez pozyskanie informacji dla powiększenia wiedzy. Pomimo tego, że procesy kognitywne mają charakter indywidualny, wielu użytkowników systemów bibliotecznych, działając samodzielnie, ma poczucie przynależności do zazwyczaj nawet kilku światów informacyjnych: użytkowników tego i innych systemów, autorów publikujących w jakiejś dziedzinie i tym podobnych grup self-trackerów. Stosują oni OPAC 2.0 i inne platformy społecznościowe tworzone dla analiz i rozpowszechniania informacji służącej tworzeniu interakcji z innymi self-trackerami i zdobywania od nich kolejnych informacji. Dla niektórych z nich ważna jest możliwość przechodzenia od bezpośredniego do zapośredniczonego komputerowo (i z powrotem) kontaktu z innymi osobami, jaką oferują biblioteki. Pozwala to wymieniać się informacją i wynikami analiz (ocenami). Z punktu widzenia działalności bibliotekarzy można mówić o tzw. narzuconym self-trackingu (Lupton, 2016b, p. 120), w którym pewna grupa zmusza innych do korzystania z narzędzi self-trackingu (w tym przypadku systemu bibliotecznego), zazwyczaj dla własnej korzyści. Jeśli chcemy korzystać z biblioteki, to musimy zgodzić się na korzystanie z jej systemu bibliotecznego (dotyczy to zarówno bibliotekarzy, jak użytkowników końcowych). W przypadku bibliotecznego self-trackingu korzyści powinny być obopólne. Wspólne korzyści powstają na przykład w przypadku, gdy gromadzone dane o zachowaniach użytkowników służą doskonaleniu usług informacyjnych.

W artykule ukazano interesujący, nowy punkt widzenia na komunikację naukową w tym działalność informacyjną biblioteki, skupiający się na indywidualnych procesach samopoznania i analizy informacji indywidualnej, gromadzonej w działaniach szeroko rozumianych użytkowników bibliotek. Procesy te składają się na doświadczenie życiowe użytkowników. Związane są one głównie z dwiema grupami działań: organizowaniem istniejącej informacji (czego efektem jest m.in. OPAC) i jej wyszukiwaniem oraz tworzeniem i rozpowszechnianiem nowej informacji. Systemy informacyjne powinny być tak projektowane, aby wspomagać te procesy. Taki punkt widzenia uwzględnia rosnącą indywidualizację procesów nauki oraz miejsce każdego naukowca w tych procesach wraz z jego osiągnięciami. Oczywiście nie tylko naukowcy, odgrywający naprzemiennie role autorów i użytkowników informacji, uczestniczą w tych 
procesach; ich uczestnikami są także bibliotekarze i inni pracownicy bibliotek. W środowisku takich, graniczących ze sobą informacyjnych światów konstruowana jest tożsamość wszystkich ich uczestników.

\section{BIBLIOGRAFIA}

Andersen, Jack (2017). Genre, organized knowledge, and communicative action in digital culture. In: The organization of knowledge: caught between global structures and local meaning. Ed. by J. Andersen, L. Skouvig. Bingley: Emerald Publ., pp. 1-16.

Andersen, Jack; Lomborg, Stine (2020). Self-tracking and metric codification in digital infrastructures for scholarly communication. The Information Society, vol. 36, no. 1, pp. 43-52.

Badurek, Jarosław (1999). Granice złożoności - prostota i kompleksowość w systemach informacyjnych. Computerworld [online], 22.02.1999 [dostęp: 14.03.2020]. Dostępny w WWW: <https://www.computerworld.pl/news/Granice-zlozonosci-prostota-i-kompleksowosc-w-systemach-informacyjnych,286595.html>.

Barbour, Kim; Marshall, David (2012). The academic online: constructing persona through the World Wide Web. First Monday [online], vol. 17, no. 9 [dostęp: 14.03.2020]. Dostępny w WWW: <http://journals.uic.edu/ojs/index.php/fm/article/view/3969>.

Carey, James (2009). Communication as culture. New York: Routledge.

Casper, Christian (2016). The online research article and the ecological basis of new digiotal genres. In: Science and the Internet: communication knowledge in a digital age. Ed. by A. Gross, J. Buehl. New York: Routledge, pp. 77-98.

Castells, Manuel (2007). Communication, power and counter-power in the network society. Intern. Journal of Communication, vol. 1, pp. 238-266.

Chan, Janet; Johns, Fleur; Moses, Lyria (2018). Academic metrics and positioning strategies. In: Metric culture: ontologies of self-tracking practices. Ed. by B. Ajana. Bingley: Emerald Publ., pp. 177-195.

Driessen, $\mathrm{O}$ (2012). The celebritization of society and culture: understanding the structural dynamics of celebrity culture. International Journal of Culture Studies, vol. 16, no. 6, pp. 641-657.

Feng, Yuanyuan; Agosto, Denise (2019). Revisiting personal information management through information practices with activity tracking technology. Journal of the ASIST, vol. 20, no. 12, pp. 1352-1367.

Fox, Nick; Alldred, Pam (2019). New materialism. In: SAGE Research Methods Foundations. Ed. by P. Atkinson et al. [online], [dostęp: 15.03.2020]. Dostępny w WWW: doi:10.4135/97815264210.

Genette, Gérard (1997). Paratexts. Thresholds of interpretation. Cambridge: Cambridge Univ. Press.

Gibson, James (1979). The ecological approach to visual perception. Boston: Houghton Mifflin.

Gross, Alan; Harmon, Joseph (2016). The Internet revolution in the sciences and humanities. Oxford: Oxford Univ. Press.

Hammarfelt, Björn; de Rijcke, Sarah; Rushforth, Alexander (2016). Quantified academic selves: the gamification of research through social networking ser- 
vices. Information Research [online], vol. 21, no. 2 [dostęp: 14.03.2020]. Dostępny w WWW: <http://informationr.net/ir/21-2/SM1.html>.

Hayles, Katherine (2006). Unfinished work: from cyborg to cognisphere. Theory, Culture \& Society, vol. 23, no. 7-8, pp. 159-166.

Herman, Eti; Nicholas, David (2019). Scholarly reputation building in the digital age: an activity-specific approach. Review article. El Profesional de la Informacion [online], vol. 28, no. 1 [dostęp: 12.03,2020]. Dostępny w WWW: <https:// recyt.fecyt.es/index.php/EPI/article/download/epi.2019.ene.02/42164>.

Jaeger, Paul; Burnett, Gary (2010). Information worlds. Social context, technology, and information behavior in the age of the Internet. New York: Routledge.

Jamali, Hamid; Nicholas, David; Herman, Eti (2016). Scholarly reputation in the digital age and the role of emerging platforms and mechanisms. Research Evaluation, vol. 25, no. 1, pp. 37-49.

Jones, William (2012). The future of personal information management. Part I: Our information, always and forever. San Rafael, CA: Morgan \& Claypool.

Jones, William (2007). Personal information management. Annual Review of Information Science and Technology, vol. 41, no. 1, pp. 453-504.

Kristensen, Dorthe; Ruckenstein, Minna (2018). Co-evolving with self-tracking technologies. New Media \& Society, vol. 20, no. 10, pp. 3624-3640.

Krzanowska, Paulina; Nahotko, Marek (2018). Gatunek information scraps w indywidualnym/grupowym zarządzaniu informacją. Zagadnienia Informacji $\mathrm{Na}$ ukowej, vol. 56, nr 2, s. 52-73.

Książek, Tomasz (2019). Bańka filtrująca i błą konfirmacji w świadomości użytkowników Internetu. Warszawa: Wydaw. SBP.

Lansdale, Mark (1988). The psychology of personal information management. Applied Ergonomics, vol. 19, no. 1, pp. 55-66.

Latour, Bruno (2005). Reassembling the social: an introduction to actor-network theory. Oxford: Oxford Univ. Press.

Liddle, Jacki et al. (2016). Balancing self-tracking and surveillance: Legal, ethical and technological issues in using smartphones to monitor communication in people with health conditions. Journal of Law and Medicine, vol. 24, no. 2, pp. 383-393.

Lomborg, Stine; Frandsen, Kirsten (2016). Self-tracking as communication. Information, Communication \& Society, vol. 19, no. 7, pp. 1015-1027.

Lupton, Deborah (2020). Self-tracking. In: Information: Keywords. Ed. by J. Abel, S. Frederick, M. Kennerly. New York: Columbia Univ. Press.

Lupton, Deborah (2016a). Digital companion species and eating data: implications for theorizing digital data-human assemblages. Big Data \& Society, vol. 3, no. 1, pp. 1-5.

Lupton, Deborah (2016b). The quantified self. A sociology of self-tracking. Cambridge: Polity Press.

Lupton, Deborah (2014). Self-tracking modes: reflexive self-monitoring and data practices [online]. [dostęp: 10.03.2020]. Dostępny w WWW: <http://dx.doi. org/10.2139/ssrn.2483549>.

Materska, Katarzyna (2012). Wymiary zarządzania informacją indywidualną. W: Społeczeństwo i sieć informacyjna. Problemy i technologie. Pod red. B. Sosińskiej-Kalaty, E. Chuchro. Warszawa: Wydaw. SBP, s. 65-79. 
Mehlenbacher, Ashley; Mehlenbacher, Brad (2019). The case of scientific research article and lessons concerning genre change online. In: Science Communication on the Internet. Ed. by M. Luzón, C. Pérez-Llanda. Amsterdam: John Benjamins Publ., pp. 41-57.

Neff, Gina; Nafus, Dawn (2016). Self-tracking. Cambridge, MA: The MIT Press.

Owen, John Mackenzie (2007). The scientific article in the age of digitization. Berlin: Springer Verl.

PLOS ONE (2019). Journal information [online]. PLOS; [dostęp: 31.03.2020]. Dostępny w WWW: < https://journals.plos.org/plosone/s/journal-information>.

PN-ISO 11620:2017-11. Informacja i dokumentacja - Wskaźniki funkcjonalności bibliotek.

PN-ISO 16439:2019-11. Informacja i dokumentacja - Metody i procedury oceny wpływu bibliotek.

Pullar-Strecker, Tom (2014). Personal informatics trends tracked [online]. [dostęp: 15.03.2020]. Dostępny w WWW: <http://www.stuff.co.nz/business/industries/ 9950896/Personal-informatics-trends-tracked>.

Rooksby, John i in. (2014). Personal tracking as lived informatics. In: CHI'14. Proc. of the SIGCHI Conference on Human Factors in Computing Systems. Toronto, April 26 - May 1, 2014. New York: ACM, pp. 1163-1172.

Ruckenstein, Minna (2014). Visualized and interacted life: personal analytics and engagements with data doubles. Societies, vol. 4, pp. 68-84.

Schull, Natasha (2016). Data for life: wearable technology and the design of selfcare. BioSocieties, vol. 11, pp. 317-333.

Skórka, Stanisław (2014). Fasety na nowo odkryte. Integrowanie systemów nawigacji i organizowania informacji. Zagadnienia Informacji Naukowej, vol. 54, nr 2, s. 92-109.

Striphas, Ted (2015). Algorimic culture. European Journal of Cultural Studies, vol. 18 , no. 4/5, pp. 395-412.

Szmigielska, Teresa (2011). Standardy oceny bibliotek akademickich. Warszawa: Wydaw. SBP.

Świgoń, M. (2012). Zarzadzanie wiedza i informacja. Podstawy teoretyczne. Badania $w$ wymiarze indywidualnym. Olsztyn: Wydaw. UW-M.

Trace, Ciaran; Zhang, Yan (2020). The quantified-self archive: documenting lives through self-tracking data. Journal of Documentation, vol. 76, no. 1, pp. 290-316.

Wendland, Michał (2011). Konstruktywizm komunikacyjny. Poznań: Wydaw. Naukowe IF UAM.

Wilson, Katie (2007). OPAC 2.0: next generation online library catalogues ride the Web 2.0 wave! Online Currents, vol. 21, no. 10, pp. 406-413.

Wójcik, Magdalena (2020). Koncepcja quantified self i jej konsekwencje dla projektowania usług bibliotecznych $\mathrm{w}$ świetle literatury przedmiotu. Przeglad Biblioteczny, R. 88, z. 1, s. 38-49.

Yoo, Youngin (2010). Computing in everyday life: a call for research on experiental computing. MIS Quarterly, vol. 34, no. 2, pp. 213-231.

Zhai, Yujia; Ding, Ying; Wang, Fang (2018). Measuring the diffusion of an innovation: a citation analysis. Journal of the ASIST, vol. 69, no. 3, pp. 368-379. 
MAREK NAHOTKO

Institute of Information Studies

Jagiellonian University

e-mail: marek.nahotko@uj.edu.pl

ORCID: 0000-0002-4823-8080

\section{QUANTIFIED SELF IN SCHOLARLY COMMUNICATION}

KEYWORDS: Quantified Self. Library system. Self-tracking. Scholarly communication.

ABSTRACT: Thesis/Objective - The author discusses two applications of Quantified Self and self-tracking in the field of scholarly communication - that is, the scholarly publishing and organization of information in libraries. Research methods - The analysis and critique of the literature in the field was used to discuss the phenomenon of Quantified Self (QS) and its applications never described before in the literature. The author made a functional analysis of sample social system dedicated to science (ResearchGate) and QS tools offered along the scholarly publications of PLOS publishing house. Similar analysis was made for integrated library systems with special focus on OPAC 2.0. Results - Quantitative measuring of human activity has been used for centuries but new computer technologies brought significant changes in this area, too. QS methods and tools, used in the first phase for the areas of health protection and physical education, have been widely applied in other domains, including the scholarly communication. The analyses made by the author proved a broad implementation of new quantitative measures in the researched areas of scholarly communication. On one hand, the application of those measures enables everyone to document human activity, including the scholarly communication and on the other hand it is used to alter the behavior (including the information behavior) of the users of new technologies with the intention of improving this behavior. Conclusions - Quantified Self and self-tracking are new trends in adjusting information systems (including library systems) used in the scholarly communication to trends in the development of computer systems of general use. In scholarly publishing those transformations are reflected by the common use of alternative measures. In library systems they are reflected with new functions of subsequent generations of those systems, which are intended to facilitate human-computer and human-human communication. 